\title{
Identifying anti-Toxocara IgG antibodies in horses of Mexico
}

\author{
[Identificação de anticorpos IgG anti-Toxocara em cavalos do México] \\ R. Heredia ${ }^{1}$, C. Romero ${ }^{2}$, G.D. Mendoza ${ }^{3}$, M. Ponce $^{4}$, J.C. Carpio ${ }^{5}$ \\ ${ }^{1}$ Doctorado en Ciencias Agropecuarias y Recursos Naturales - Centro Universitario UAEM Amecameca \\ Universidad Autónoma del Estado de México-Amecameca-Estado de México, México \\ ${ }^{2}$ Centro Universitario UAEM Amecameca- Universidad Autónoma del Estado de México \\ Amecameca, Estado de México, México \\ ${ }^{3}$ Universidad Autónoma Metropolitana- Unidad Xochimilco- D.F., México \\ ${ }^{4}$ Instituto Nacional de Pediatría- D.F., México \\ ${ }^{5}$ Instituto de Diagnóstico y Referencia Epidemiológicos - InDRE -D.F., México
}

\begin{abstract}
Both the presence of owned dogs and stray dogs allows the spread of Toxocara, a parasite whose eggs can be found in soil, water and food. Animals, including horses, serve as definitive and paratenic hosts. In México, where consumption of horse meat is common, Toxocara is a zoonotic parasite. The aim of this study was to identify the presence of anti-Toxocara antibodies in work horses and horses intended for human consumption by ELISA. ELISA was chosen for analysis as paratenic hosts do not shed Toxocara eggs in their feces. Blood samples were collected from a total of 188 horses, 94 of which were work horses and 94 horses from the slaughter house. Samples were analyzed by ELISA, and the general equine seroprevalence was found to be $44.6 \%(\mathrm{n}=188)$. Adult horses for slaughter had a $61.7 \%$ greater presence of anti-Toxocara antibodies $(p=$ 0.006). Toxocara IgG antibodies were found in horses, confirming that horses are paratenic hosts and possible sources of infection for other animals and people.
\end{abstract}

Keywords: horses, Toxocara, public health, zoonoses

\section{RESUMO}

Tanto a presença de cães com dono quanto de cães vadios permitem a disseminação de Toxocara, e o parasita está presente no solo, na água e nos alimentos. Animais, incluindo cavalos, apresentam-se como hospedeiros definitivos e paratênicos. No México, o consumo de carne de cavalo é comum, e Toxocara é um parasita zoonótico. ELISA foi escolhido para análise, já que hospedeiros paratênicos não jogam ovos de Toxocara em suas fezes. O objetivo deste estudo foi identificar a presença de anticorpos anti-Toxocara por ELISA, em cavalos de trabalho e em cavalos para o consumo humano. As amostras de sangue foram retiradas de 188 cavalos: 94 cavalos de trabalho e 94 cavalos de trabalho do matadouro. Soros dos animais foram analisados por ELISA e 44,6\% dos equinos apresentaram anticorpos anti-Toxocara. Cavalos adultos para abate têm $61,7 \%$ mais elevada a presença de anticorpos anti-Toxocara $(P=0,006)$. Anticorpos IgG Toxocara foram encontrados em cavalos, confirmando cavalos paratênicos como hospedeiros e possíveis fontes de infecção para outros animais e pessoas.

Palavras-chave: Toxocara, cavalos, saúde pública, zoonoses

\section{INTRODUCTION}

Toxocara spp. are nematodes in the order Ascaridida, superfamily Ascaridoidea, and family Toxocaridae (Despommier, 2003). The biotic potential of Toxocara is huge from an epidemiological point of view, as a female can produce up to 200,000 eggs per day (Martinez et

Recebido em 3 de setembro de 2016

Aceito em 19 de janeiro de 2017

*Autor para correspondência (corresponding author)

E-mail: cromeron@uaemex.mx al., 2008). Toxocara eggs pass unembryonated in the feces of their hosts, and become infective in suitable environments (Won et al., 2008). They can remain infectious in the soil for varying time periods, ranging from days to years (Babiker et al., 2009; Romero et al., 2011). It was previously thought that transmission could only occur through ingestion of embryonated eggs after exposure to soil, water, fruit or vegetables 
contaminated with dog feces or cat hair; however, infective-stage larvae can also be transferred to other animals and humans through predation. Parasite transmission is now often associated with cases of toxocariasis in adults (Yoshikawa et al., 2008). After ingestion by nondefinitive hosts, the eggs undergo a somatic cycle resulting in the presence of larvae in tissues, where they are potentially infectious. This type of transmission is called paratenesis (Glickman and Schantz, 1981; Magnaval et al., 2001). The parasite can also be transmitted to humans through the consumption of offal, poultry (Taira et al., 2011) and other mammals that are paratenic hosts of Toxocara (Ferreira et al., 2014). In chicken muscle, the larvae can remain infective for a year (Taira et al., 2011). There are also reports of adult human toxocariasis caused by the consumption of undercooked meat or liver from paratenic hosts (Yoshikawa et al., 2008). Moreover, viable Toxocara larvae have been found in chickens (Taira et al., 2011; Ferreira et al., 2014), cattle (Yoshikawa et al., 2008), sheep (Lloyd, 2006) and pigs (Taira et al., 2004).

Infections caused by endoparasites, such as helminths, are one of the most important pathogenic factors affecting horses worldwide. Infection can cause respiratory symptoms, in addition to weakness and poor performance (Brady and Wade, 2009; Francisco et al., 2009). Coprological techniques are currently used for diagnosis; however, a significant limitation of these techniques is the unreliability of egg counts, as they are not directly related to the actual parasite load (Andersen et al., 2013). For this reason, fecal tests are unable to diagnose the migrating parasite stages (Heredia et al., 2014). Over the past two decades, the development of more sensitive and specific immunodiagnostic tests has improved knowledge of toxocariasis, which is undoubtedly the most prevalent helminth infection in industrialized countries (Magnaval et al., 2001). Use of enzyme-linked immunosorbent assay (ELISA) for antibody detection is the preferred method for the diagnosis of such parasites (Heredia et al., 2014).

\section{MATERIALS AND METHODS}

A total of 188 equine blood samples, collected from 113 females and 75 males, were analyzed for the presence of IgG antibodies to Toxocara. Of these, 94 Creole horses were slaughtered for human consumption (48 females and 46 males) and 94 animals were from the mounted police force (57 Mexican Sport breed and 37 Creole breed; 27 females and 67 males). For each horse, $5 \mathrm{ml}$ of blood was collected from the jugular vein into Vacutainer ${ }^{\circledR}$ tubes without an anticoagulant. Blood samples were kept at the ideal storage temperature (between 1 and $6^{\circ} \mathrm{C}$ ) in a heatinsulating container during transportation to the laboratory. The blood samples were processed at the Laboratory of Experimental Parasitology, National Institute of Pediatrics, in México City. Samples were centrifuged at $4000 \mathrm{~g}$ for $10 \mathrm{~min}$, and the serum was transferred to Eppendorf ${ }^{\circledR}$ tubes for ELISA analysis. A commercial ELISA kit was used (Toxocara Microwell Serum indirect ELISA, anti-Toxocara IgG antibody; SCIMEDX Richboynton Rd, Dover, NJ 07801, EE. UU), based on detection of excretionsecretion antigens of second stage Toxocara larvae at a dilution of 1:64, using protein A conjugated to the peroxidase. The optical density (OD) of the samples was determined using a Microplate $\quad$ Modulus ${ }^{\circledR}$ multiplate spectrophotometer (Turner Biosystems, Kampenhout, Belgium) at a wavelength of 460 $\mathrm{nm}$. Samples with an OD greater than 0.3 were considered positive for Toxocara. Data were statistically analyzed using Fisher's exact test for comparison between groups (McDonald, 2008).

\section{RESULTS}

The seroprevalence of Toxocara in the 188 horses tested was $44.6 \%$, with a seroprevalence of $13.8 \%(\mathrm{n}=94)$ in the working horse group and $75.5 \%(n=94)$ in the horses for slaughter. No difference in seroprevalence was found between genders in either group (Tab. 1). There was also no age difference in the seroprevalence of work horses, whereas $61.7 \%(p=0.006)$ of adult horses for slaughter showed a higher presence of anti-Toxocara antibodies (Table 1). There was no difference between breeds of work horses (Table 2), which could not be evaluated for horses for slaughter as they were all Creole horses. There was no difference in antibody presence between pregnant and non-pregnant female work horses (Table 3). None of the horses for slaughter were pregnant. 
Identifying anti-Toxocara IgG...

Table 1. Comparison between gender and age of work horses and slaughterhouse horses for the presence of Toxocara antibodies

\begin{tabular}{lcccc} 
Gender/age & Positive (\%) & Negative (\%) & Total & $p$-value \\
\hline Working horses & $4(14.81)$ & $23(85.18)$ & & \\
Female & $9(13.43)$ & $58(86.56)$ & 27 & 0.40 \\
Male & 13 & 81 & 97 & \\
Total & & $10(10.64)$ & 48 & \\
Horses for slaughter & $38(40.43)$ & $13(13.83)$ & 46 & 0.27 \\
Female & $33(35.11)$ & 23 & 94 & \\
Male & 71 & $9(81.81)$ & 11 & 0.47 \\
Total & $2(18.18)$ & $62(84.93)$ & 73 & 0.40 \\
Working horses & $11(15.06)$ & $10(100)$ & 10 & 0.20 \\
Foals & $0(0)$ & 81 & 94 & \\
Adults & 13 & $6(6.38)$ & 14 & 0.08 \\
Geriatric & $8(8.51)$ & $12(12.77)$ & 70 & $\mathbf{0 . 0 0 6}$ \\
Total & $58(61.70)$ & $5(5.32)$ & 10 & 0.06 \\
Horses for slaughter & $5(5.32)$ & 23 & 94 & \\
Foals & 71 & & \\
Adults & & & \\
Geriatric & & & \\
Total & &
\end{tabular}

*Fisher exact test $(\mathrm{P}<0.05)$.

Table 2. Differences between breeds of work horses for the presence of Toxocara antibodies

\begin{tabular}{lclcc} 
& \multicolumn{2}{c}{ Negative $(\%)$} & Total & $p$-value \\
\hline Breed & $8(14.03)$ & $49(85.96)$ & 57 & \\
Creole & $5(13.51)$ & $32(86.48)$ & 37 & 0.50 \\
Total & 13 & 81 & 94 &
\end{tabular}

Fisher exact test $(\mathrm{P}<0.05)$

Table 3. Presence of Toxocara antibodies among pregnant and non-pregnant female work horses

\begin{tabular}{|c|c|c|c|c|}
\hline & Pregnant (\%) & Nonpregnant $(\%)$ & Total & $p$-value \\
\hline Positive & $1(25)$ & $4(75)$ & 5 & \\
\hline Negative & $9(39.13)$ & $14(17.39)$ & 23 & 0.39 \\
\hline Total & 10 & 18 & 28 & \\
\hline
\end{tabular}

Fisher exact test $(\mathrm{P}<0.05)$

\section{DISCUSSION}

This study is important as it is the first to evaluate equine sera for the presence of $\mathrm{IgG}$ antibodies against Toxocara. Although the horse is not a definitive host of Toxocara, a high seroprevalence $(44.6 \%)$ was found for both groups. A study conducted by Lloyd (2006) in Wales reported the seroprevalence of Toxocara canis at $7 \%$ and $13 \%$ in two groups of sheep at 6 months of age, $16 \%$ in sheep at 10 months, $27 \%$ and $31 \%$ in sheep at 15 months and $47 \%$ of adult sheep, the samples were obtained in Slaughterhouses and farms. Alvares et al. (2011) conducted a study in southeastern Brazil and reported a Toxocara seroprevalence of $50.1 \%$ in sheep. In the city of Thessaly in Greece, Kantzoura et al. (2013) sampled 361 sheep from organic farms and found a $42 \%$ seroprevalence of Toxocara antibodies by ELISA. These studies showed a similar seroprevalence to that found in the current study, and while they did not study the same species, sheep are paratenic hosts that live and feed in similar conditions to horses.

The horses for human consumption $(\mathrm{n}=94)$ had a higher seroprevalence $(75.5 \%)$, indicating that these animals could have migrating Toxocara 
larvae or somatic hypobiotic larvae, which could represent a risk factor for toxocariasis when consumed. The difference in seroprevalence between horses intended for food $(75.5 \%)$ and work $(13.8 \%)$ can be attributed to the fact that working horses were stabled most of the time when they were not working, whereas horses for slaughter grazed in pastures. This is supported by a study by O'Meara and Mulcahy (2002), who demonstrated that eggs and larvae can survive in the pasture at both low and high temperatures, leading to an accumulation of infective stages in meadows. Therefore, horses of all ages, gender and use are susceptible to Toxocara infection when grazing. Francisco et al. (2009) found that silvopastoralism increased the frequency of gastrointestinal helminth infections in horses due to contamination of pastures with nematodes. Samson (2011), Matthews (2014) and Nielsen et al. (2014) also argued that horses are exposed to a variety of gastrointestinal nematodes worldwide, and animals that feed on contaminated pastures are not treated with effective anthelmintics, which can lead to the accumulation of large numbers of parasites. In this study, no difference was found between male and female animals, indicating that there was no predisposition to parasitism by gender in either working or slaughterhouse horses. This is consistent with the findings of Prochno et al. (2014), who conducted a study of the seroprevalence rates of antibodies against Theileria equi in team roping horses and evaluated variables inherent to equine species, such as gender and age. These authors reported that these factors were not associated with $T$. equi positivity, as 127 males and 125 females were found to be positive. In the current study, no difference in seroprevalence was found between working horses of different ages, whereas adult horses for slaughter had a higher amount of antibodies. This is similar to the results of Hinney et al. (2011), who sampled horses on horse farms in Germany, and reported that younger animals had a higher prevalence of ascarids, which decreased with increasing age, this supports our finding that animals had no difference between the ages and seroprevalence this only of working horses, although it is contrary to what we find in slaughter horses because adult horses presented higher seroprevalence. In our study, there was no difference between breeds of work horses, which is in contrast to that reported in the study by
Hinney et al. (2011), who reported that heavy horse breeds had a higher risk $(\mathrm{OR}=3.63, p=$ 0.001 ) of being parasitized, the wild horses presented a OR $=4.94$ and $p=0.005$, the thoroughbreds while OR was " 1 " and warmblooded horses or Arabian horses presented OR $=1.07$ and $p=0.756$, showing that there was a difference between breeds. In our study, horses for slaughter were not analyzed for differences between breeds as they were all Creole horses.

\section{CONCLUSION}

The results of this study demonstrated that horses are paratenic hosts for Toxocara with a high seroprevalence, especially those intended for slaughter. This translates to a risk for human toxocariasis, as consumption of horse meat is common in México and some Latin American countries, and farms and slaughterhouses exist for this purpose.

\section{ETHICAL ANIMAL RESEARCH}

This work was approved by the Ethics Committee of the Amecameca University Center of the Autonomous University of the State of Mexico. The work horses sampled in this study were owned by the mounted police, and informed consent was obtained before sampling. In the case of horses for slaughter, samples were collected post-mortem.

\section{REFERENCES}

ALVARES, V.; FABRIS, P.A.; LEME, B.E. et al. Anti-Toxocara spp. antibodies in sheep from southeastern Brazil. Vet. Parasitol., v.179, p.283286, 2011.

ANDERSEN, U.V.; HOWE, D.K.; OLSEN, S.N. et al. Recent advances in diagnosing pathogenic equine gastrointestinal helminths: the challenge of prepatent detection. Vet. Parasitol., v.192, p.1-9, 2013.

BABIKER, A.; ALI, S.; AHMED, S. Frequency of intestinal parasites among food-handlers in Khartoum, Sudan. East Mediterr. Health J., v.15, p.1098-1104, 2009.

BRADY, H.; WADE, N. Review: drug resistance in equine parasites: an emerging global problem. J. Equine Vet. Sci., v.29, p.285-295, 2009. 
DESPOMMIER, D. Toxocariasis: clinical aspects, epidemiology, medical ecology, and molecular aspects. Clin. Microbiol. Rev., v.16, p.265-271, 2003.

FERREIRA, D.G.; FRANÇA P.N.S.; FARIAS DA COSTA, A.L. et al. Risk of infection by the consumption of liver of chickens inoculated with low doses of Toxocara canis eggs. Vet. Parasitol., v.203, p.87-90, 2014.

FRANCISCO, I.; ARIAS, M.; CORTIÑAS, F. et al. Silvopastoralism and autochthonous equine livestock: analysis of the infection by endoparasites. Vet. Parasitol., v.164, p.357-362, 2009.

GLICKMAN, L.T.; SCHANTZ, P.M. Epidemiology and pathogenesis of zoonotic toxocariasis. Epidemiol. Rev., v.3, p.230-250, 1981.

HEREDIA, R.; ROMERO, C.; MENDOZA, G.E. et al. Ocurrence of Toxocara canis in students of veterinary and graphic design in a Mexican university. Acta Sci. Vet., v.42, p.1-6, 2014.

HINNEY, B.; WIRTHERLE, N.; KYULE, M. et al. Prevalence of helminths in horses in the state of Brandenburg, Germany. Parasitol. Res., v.108, p.1083-1091, 2011.

KANTZOURA, V.; DIAKOU, A.; KOUAM, M. et al. Seroprevalence and risk factors associated with zoonotic parasitic infections in small ruminants in the Greek temperate environment. Parasitol. Int., v.62, p.554-560, 2013.

LLOYD, S. Seroprevalence of Toxocara canis in sheep in Wales. Vet. Parasitol. v.137, p.269-272, 2006.

MAGNAVAL, J.F.; GLICKMAN, L.T.; DORCHIES, P. et al. Highlights of human toxocariasis. Korean J. Parasitol., v.39, p.1-11, 2001

MARTINEZ, I.E.; GUTIERREZ， C.M.; ALPIZAR, E.A. et al. Parasitic contamination by dog feces collected from the streets of San Cristobal de Las Casas, Chiapas, Mexico. Vet. Mex., v.39, p.173-180, 2008.

MATTHEWS, J. Anthelmintic resistance in equine nematodes. Int. J. Parasitol. Drugs Drug Resist., v.4, p.310-315, 2014.
MCDONALD, J.H. Fisher's exact test of independence. In: Handbook of biological statistics. Maryland: Sparky House Publishing, 2008. p.63-68.

NIELSEN, M.; PFISTER, K.; VON SAMSONHIMMELSTJERNA, G. Selective therapy in equine parasite control-application and limitations. Vet. Parasitol., v.202, p.95-103, 2014.

O'MEARA, B.; MULCAHY, G. A survey of helminth control practices in equine establishments in Ireland. Vet. Parasitol., v.109, p.101-110, 2002.

PROCHNO, H.C.; MILLÉO, L.; RODRIGUES, F. et al. Seroprevalence rates of antibodies against Theileria equi in team roping horses from central-western region of Paraná, Braz. J. Vet. Parasitol., v.23, p.85-89, 2014.

ROMERO, C.; MENDOZA, G.; BUSTAMANTE, L. et al. Presence and viability of Toxocara Spp. in soils of public parks, gardens of houses and feces from dogs in Nezahualcóyotl, México. Rev. Cient. FCV-LUZ, v.21, p.195-201, 2011

SAMSON-HIMMELSTJERNA, G. Anthelmintic resistance in equine parasites - detection, potential clinical relevance and implications for control. Vet. Parasitol., v.185, p.2-8, 2011.

TAIRA, K.; SAEED, I.; PERMIN, A. et al. Zoonotic risk of Toxocara canis infection through consumption of pig or poultry viscera. Vet. Parasitol., v.121, p.115-124, 2004.

TAIRA, K.; SAITOH, Y.; KAPEL, C.M.O. Toxocara cati larvae persist and retain high infectivity in muscles of experimentally infected chickens. Vet. Parasitol., v.180, p.287-291, 2011.

WON, Y.; KRUSZON, D.; SCHANTZ, M. et al. National seroprevalence and risk factors for zoonotic Toxocara spp. infection. Am. J. Trop. Med. Hyg., v.79, p.552-557, 2008.

YOSHIKAWA, M.; NISHIOFUKU, M.; MORIYA, K. et al. A familial case of visceral toxocariasis due to consumption of raw bovine liver. Parasitol. Int., v.57, p.525-529, 2008. 